\title{
O QUE CONSERVAR PARA NÃO SERMOS CONSERVADORES? REVISITANDO HANNAH ARENDT
}

Flávio Rovani de Andrade*

Resumo: O presente artigo pretende, à luz de Hannah Arendt, discutir alguns pontos atinentes ao pensamento conservador, sobretudo no que se refere ao atual momento político e social brasileiro, que, nos últimos anos, vem presenciando o acirramento das disputas político-ideológicas e, por conseguinte, o crescimento de grupos declaradamente conservadores.

Palavras-chave: conservadorismo, liberdade, política, democracia.

Abstract: This article aims in light of Hannah Arendt, discuss some points pertaining to conservative thinking, especially with regard to the current Brazilian political and social moment, which in recent years has been witnessing the intensification of political and ideological disputes and therefore, the growth reportedly conservative groups.

Keywords: conservatism, liberty, politics, democracy.

\section{Introdução}

O tema do conservadorismo revela importância num contexto em que ganha força as gigantescas manifestações entre pessoas que pouco ou nada possuem em comum, reunidas nas chamadas redes sociais, onde as relações entre as pessoas carecem, justamente, de relacionamento: é-se amigo de quem não conhece, opina-se sobre o que não sabe, e assim por diante. Mais sério são os desdobramentos das acirradas eleições para Presidente da República, em que a parte sul do país, movida por camadas mais abastadas e majoritariamente brancas, passaram a aludir a separação do Brasil, reforçando ódios e preconceitos históricos tanto aos povos do Norte e,

** Doutor em Filosofia e História da Educação pela Faculdade de Educação da Universidade Estadual de Campinas FE-UNICAMP. Mestre na área de Filosofia da Educação pela Faculdade de Educação da Universidade de São Paulo - FE-USP, 2008. Professor de Filosofia Geral e da Educação na Universidade Federal do Piauí (UFPI). É autor de livros e artigos acadêmicos nas áreas de Filosofia e Educação. 
especialmente, do Nordeste, quanto aos pobres, afrodescendentes, indígenas, imigrantes, homossexuais etc., que ergueram as sociedades sulistas e sudestinas. Some-se setores que defendem um novo golpe militar e aqueles que querem Paulo Freire longe das escolas, e temos um ambiente claramente "conservador".

Entretanto, se há o efetivo interesse de compreender, à luz de Hannah Arendt, essas questões, é preciso desfazer um primeiro embaraço: esqueçamos a dicotomia conservador/progressista, pois nenhum dos polos resiste ao processo de massificação. No limite, o que temos com Arendt é a compreensão de como a ação política, típica da esfera pública, se perde na sociedade (esfera social), e como esta por sua vez se desdobra em sociedade de massas.

Para que possamos nos munir do acervo categorial de Arendt de modo a nos aproximar do entendimento destas questões, precisaremos dar os seguintes passos: primeiramente, compreenderemos a vita activa, constituída pelo trabalho, pela obra e pela ação, e suas interfaces com a natalidade e a liberdade. Na sequência, buscaremos entender o sentido da política, a liberdade e a esfera pública, assim como o mundo e o senso comuns. Por fim, compreenderemos a leitura que Arendt faz da emergência da sociedade e da sociedade de massas.

Após estas primeiras aproximações, buscaremos responder à seguinte pergunta: o que conservar para não sermos conservadores?

\section{A vita activa: trabalho, obra, ação}

Ao conceber basicamente três atividades que caracterizam a vita activa, o trabalho, a obra e a ação, Arendt mostra que por mais que se queira alienar-se da vita activa, não é possível sair completamente dela, pois mesmo no refúgio voluntário da contemplação, "ninguém pode permanecer em estado contemplativo durante toda sua vida" (ARENDT, 2005, p. 176). Isso quer dizer, de outro modo, que a vita activa "é não apenas aquela em que a maioria dos homens está engajada, mas ainda aquela de que nenhum homem pode escapar completamente" (Arendt, 2005, p. 176). Ela se define, então, como "a vida humana na medida em que está ativamente empenhada em fazer algo" (Arendt, 2010a, p. 26), isto é, trabalhar, fabricar e agir. Arendt, em uma disposição incomum, diferencia fenomênica e conceitualmente trabalho e obra. Segundo ela, há pouquíssimas manifestações claras sobre essa distinção na história do pensamento, salvo algumas referências acidentais. Mas insiste nela, pois considera a diferença fenomênica marcante. Ela infere 
preliminarmente a diferenciação "de uma observação um tanto casual de Locke, que fala do 'trabalho de nosso corpo e da obra de nossas mãos"” (Arendt, 2005, p. 179). Cada uma das três atividades corresponde a uma condição humana específica, respectivamente, a vida, a mundanidade e a pluralidade. Essas condições, por sua vez, refletem uma condição humana mais geral, que é a própria natalidade, a qual deveria ser, para a autora, a categoria central do pensamento político.

O trabalho é a atividade que tem por objetivo a manutenção da vida, entendida como vida biológica, ou seja, "corresponde ao processo biológico do corpo humano, cujo crescimento espontâneo, metabolismo e resultante declínio estão ligados às necessidades vitais" (Arendt, 2010a, p. 08). O trabalho produz coisas para o consumo, que são tão imediatamente consumidas quanto as necessidades novamente se impõem tão logo satisfeitas. São "[coisas] produzidas e consumidas de acordo com o sempre-recorrente movimento cíclico da natureza" (Arendt, 2010a, p. 119), o movimento da vida e da morte. A condição humana do trabalho é a própria vida, que por sua vez consome a durabilidade de tudo que é produzido pelo trabalho. Do ponto de vista de sua duração, por estar inserido no ciclo orgânico da vida, o trabalho é igualmente cíclico, semprerecorrente, possuindo "apenas pausas, intervalos entre a exaustão e a regeneração" (Arendt, 2005, p. 185), não possuindo começo nem fim.

A obra, ou fabricação, é atividade que condiz com a artificialidade humana, isto é, “corresponde à não-naturalidade [unnaturalness] da existência humana" (Arendt, 2010a, p. 08). A obra, então, não está presa ao sempre-recorrente ciclo da natureza, mas pelo contrário, produz um mundo de coisas artificiais claramente diferentes "de qualquer ambiente natural" (Arendt, 2010a, p. 08). Sua condição humana é a mundanidade, na medida em que a obra implica a construção do mundo. "O processo da fabricação é inteiramente determinado pelas categorias dos meios e do fim" (Arendt, 2005, p. 185), sendo medida por critérios de utilidade. Seu resultado, o artefato, pode ser entendido como resultado final em dois sentidos: por um lado, o produto chega ao fim no momento de sua fabricação; por outro, é um meio para a produção desse fim. Diferentemente do trabalho, por não estar subjugada às necessidades da vida, a obra não produz coisas efêmeras para o consumo, mas objetos de uso. O uso, ao invés do consumo, não é fugaz e imediatista. $\mathrm{O}$ uso correto de objetos da obra não os consome, não causa desaparecimento, embora os desgaste. Os artefatos produzidos pelo processo de fabricação, em infinita variedade, "dão ao mundo a 
estabilidade e a solidez sem as quais não se poderia contar com ele para abrigar a criatura mortal e instável que é o homem" (Arendt, 2005, p. 183).

Nesse sentido, fica clara a necessidade de diferenciação entre mundo e natureza em Arendt. O mundo é uma construção humana, sendo que quando a autora utiliza o termo em sentido forte ela se refere ao mundo humano, na relação recíproca entre o homem que fabrica coisas e essas coisas que condicionam o homem. É no mundo de coisas feitas como obra de suas mãos que a vita activa, os assuntos humanos, se desenrolam. Ao ciclo vital é inerente a não-permanência, o fluxo constante, e na pura realidade natural o homem seria reduzido ao seu metabolismo com a natureza, ao mínimo denominador comum que possui com quaisquer outras espécies de seres vivos. Enquanto construtor do mundo, homo faber, o ser humano acrescenta à sua condição os objetos da obra que não o condicionam apenas no sentido primário de transformar o mundo (que por sua vez transforma o homem), mas também no sentido de não estarem destinados ao consumo, uma vez que os objetos da fabricação infundem durabilidade no ciclo dos efêmeros, tornando o mundo algo estável (mas não estático), no qual os homens podem se sentir em casa. Assim, ao assumir uma duradoura relação com o homem, o artefato adentra ao seu mundo e torna-se condição de sua existência. "O impacto da realidade do mundo sobre a existência humana é sentido e recebido como força condicionante" (Arendt, 2010a, p. 11). Esse caráter condicionante das coisas do mundo e essa existência condicionada do homem no mundo são complementares, pois sem tais coisas não haveria existência eminentemente humana, assim como as coisas seriam aglomerados de artefatos desconexos. Entregues a si, os objetos de uso se desintegrariam e deixariam de ser mundanos, retornando ao ciclo da natureza. Nesse sentido, para que se possa ter no mundo um lar, é preciso que ele seja minimamente confiável, ou seja, possua maior ou menor permanência (cf. Arendt, 2010a, p. 118). O mundo é confiável na medida em que nos vemos cercados de coisas cuja durabilidade e permanência são maiores que a atividade que as produziu - isto é, mais permanentes que os objetos oriundos do trabalho -, e possivelmente mais longos que o período de vida de quem as fez. Assim as coisas do mundo, para que sejam de fato mundanas, são relativamente independentes daqueles que as fazem e usam. Ou seja, a durabilidade confere-lhes a ““objetividade' que as faz resistir, 'se opor' e suportar, ao menos por um tempo, as necessidades e carências vorazes de seus usuários vivos" (Arendt, 2005, p. 184; 2010a, p. 170). O mundo, nesse aspecto, é estabilizante da vida, e os homens podem recorrer ao mundo e restituir sua permanência na objetividade mundana. "[...] contra a subjetividade dos homens afirma-se a objetividade do 
mundo feito pelo homem" (Arendt, 2010a, p. 171; 2005, p. 184), em vez de uma natureza que lhe é indiferente e que o faria tornar ao centro vital. Conclui Arendt: "Somente porque erigimos um mundo de objetos a partir do que a natureza nos dá e construímos um ambiente artificial na natureza, protegendo-nos assim dela, podemos considerar a natureza como algo 'objetivo"” (Arendt, 2005, p. 184; 2010a, p. 171). Em síntese, as coisas do mundo, provenientes da atividade da obra, ao estabilizarem o homem em um mundo objetivo, asseguram-lhe existência entre as coisas mais ou menos permanentes, sem as quais a catástrofe seria inevitável se ficassem entregues ao sempre-recorrente ciclo biológico; seria o homem reduzido ao mínimo denominador comum que guarda com as demais espécies vivas, que seria o ciclo ininterrupto do trabalho voltado a um eu inumano e sem mundo.

A ação é a única dentre as atividades que ocorrem apenas entre os homens, "sem mediação das coisas ou da matéria" (Arendt, 2010a, p. 08), e se empenha em formar corpos políticos, isto é, espaços comuns nos quais se possam gestar significações compartilhadas, além de ser o espaço para que se empreenda algo novo. O trabalho é cíclico, sem começo nem fim; a obra tem começo e fim determinados no objeto produzido; a ação tem começo definido, mas seu fim não pode ser previsto. A manifestação da ação é a fala. É pela qualidade discursiva que incidimos, quando de forma legítima, sobre os outros, sem uso de meios de violência. Ao contrário tanto do trabalho do corpo quanto da obra das mãos, que podem afastar-se dos outros para que sejam realizados, a ação só pode acontecer diante dos outros, nunca no isolamento. "Estar isolado é estar privado da capacidade de agir" (Arendt, 2010a, p. 235). A fabricação precisa estar circundada pela natureza, de onde extrai sua matéria-prima, e pelo mundo em que introduz seus artefatos. O agir e o discurso não produzem coisas permanentes e duráveis; a rigor, nem mesmo chegam a produzir algo, mas "são tão fúteis quanto a vida" (Arendt, 2010a, p. 117). Daí, para que possa firmar-se como mundana, a ação, por meio da fala, precisa ser vista, ouvida e lembrada; sem isso, simplesmente passam, não ganham materialidade e não se reificam; apenas na medida em que sua futilidade se impõe com força dignificante aos outros, é que tornam-se "feitos, fatos, eventos e modelos de pensamentos e ideias" (Arendt, 2010a, p. 117). Assim, oriunda do pensamento - a atividade mais livre do espírito, da vita contemplativa -, a ação, que se insere no mundo pela fala, "corresponde à condição humana da pluralidade, ao fato de que os homens, e não o Homem, vivem na Terra [no sentido de planeta, natureza da qual pertencem e pela qual trabalham] e habitam o mundo [dos artefatos humanos]" (Arendt, 2010a, p. 08). 
A pluralidade é, para Arendt, a condição humana que se insere na complementaridade, inerente à teia de relações humanas, entre igualdade e diferença. Os homens são iguais enquanto partilham da mesma humanidade, não como essência de caráter metafísico, mas como fenômeno humano. São diferentes pelo fato de que cada qual nasce um, sempre novo e jamais é igual a qualquer outro que já existiu ou venha a existir. Isto é, os homens são iguais em sua singularidade: "No homem, a alteridade, que ele partilha em tudo o que existe, e a distinção, que ele partilha com tudo o que vive, tornam-se unicidade, e a pluralidade humana é a paradoxal pluralidade de seres únicos" (Arendt, 2010a, p. 220). A ação é o oposto do mero comportamento, pois esse, conforme denomina a autora, é a repetição continuamente reproduzível, operando-se sem distinção em indivíduos diferentes de uma mesma espécie animal. Os animais comportam-se igualmente, pois carecem de singularidade, e embora possam viver em manadas, são absolutamente iguais ao responderem automaticamente às necessidades da vida. A ação corresponde ao fato de os seres humanos não serem absolutamente comportamentais, insurgindo-se singularmente contra as leis gerais do comportamento, pois os seres humanos são não apenas distintos, mas plurais.

Obviamente, Arendt admite uma hierarquia entre essas três atividades, ocupando a ação o posto mais alto. Olhando do ponto de vista da história do pensamento filosófico, geralmente a ação não ocupa o mais alto posto, pois para a filosofia a vita contemplativa é sobreposta à vita activa. $\mathrm{Na}$ modernidade, quando a própria filosofia inverte essa ordem de prioridade, alocando o âmbito da vida ativa por sobre a contemplação, fá-lo pela "glorificação do trabalho" (Arendt, 2005, p. 178). Dessa forma, a autora toma sua concepção de hierarquia da vida ativa no sentido antigo da atividade pré-filosófica e pré-platônica, isto é, da experiência da polis grega. Aos olhos da contemplação filosófica, explica ela, "a atividade mais elevada não era a ação, mas a fabricação" (Arendt, 2005, p. 178), posto que a ação deveria produzir no campo dos assuntos humanos os efeitos daquelas essências conhecidas tão somente pela contemplação. O resultado permanente da ação, sob a forma da fabricação, era a estabilidade e a paz necessárias ao próprio ato da contemplação. No campo da filosofia antiga, grosso modo, theoria (vita contemplativa) se sobrepunha à práxis e à poiésis, sendo que a práxis poderia estar no máximo ao lado da theoria. À luz de Arendt, entretanto, essa práxis opera-se, no mesmo pensamento grego, ao modo de parte do significado de poiésis, uma vez que não havia indicação de uma consciência teórica que derivasse da palavra poiésis os conceitos de trabalho e fabricação ${ }^{3}$. De qualquer modo, na praça ou no ${ }^{3}$ Arendt inicia a seção 12 de $A$ condição humana, que trata de "O caráter de coisa do mundo", analisando o fato de o trabalho ter passado do antigo desprezo à moderna glorificação. Anteriormente, na seção 11, sob o título "O trabalho 
pensamento, o trabalho sempre foi, aos olhos pré-modernos, a atividade humana de mais baixo nível. Para Arendt, entretanto, esclarecidas essas distinções conceituais e fenomênicas, a ação, irredutível ao trabalho e à obra, é a mais alta expressão da vita activa.

\section{Natalidade e liberdade}

Todas as atividades, independentemente de seu grau na hierarquia da vita activa, têm seu enraizamento no fato da natalidade. A vida, a mundanidade e a pluralidade são, respectivamente, condições humanas do trabalho, da obra e da ação. Todas essas condições específicas de cada atividade têm relação com o espaço entre o nascer e o morrer, que são condições humanas mais gerais: o trabalho com relação ao viver e morrer na natureza, a obra em relação ao viver e morrer no mundo, a ação em relação ao nascer e ao morrer entre os homens. Nesse ponto, é importante distinguir conceitualmente nascimento e natalidade, embora terminologicamente ambos remetam ao verbo "nascer". Pelo nascimento se vem à vida; finda a vida, chega a morte - isso, os homens partilham com todos os seres vivos. Pela natalidade se nasce para e no mundo, espaço em que os homens vivem por entre coisas por eles criadas e entre aqueles com quem se pode agir.

Sobre essa relação entre a vita activa e a natalidade, diz Arendt:

Todas as três atividades e suas condições correspondentes estão intimamente relacionadas com a condição mais geral da existência humana: o nascimento e a morte, a natalidade e a mortalidade. O trabalho assegura não apenas a sobrevivência do indivíduo, mas a vida da espécie. A obra e seu produto, o artefato humano, conferem uma medida de permanência e durabilidade à futilidade da vida mortal e ao caráter efêmero do tempo humano. A ação, na medida em que se empenha em fundar e preservar corpos políticos, cria a condição para a lembrança [remembrance], ou seja, para a história. O trabalho e a obra, bem como a ação, estão também enraizados na natalidade, na medida em que têm a tarefa de prover e preservar o mundo para o constante influxo de recém-chegados que nascem no mundo como estranhos, além de prevê-los e levá-los em conta. Entretanto, das três atividades, a ação tem a relação mais estreita com a condição humana da natalidade; o novo começo inerente ao nascimento pode fazer-se sentir no mundo somente porque o recém-chegado possui a capacidade de iniciar algo novo, isto é, de agir. Nesse sentido de iniciativa, a todas as atividades humanas é

de nosso corpo e obra de nossas mãos" (Arendt, 2010a, p. 98), entre aspas, ela tece considerações sobre o fato de, além das evidências fenomênicas, haver nas línguas ocidentais sempre duas palavras para designar as atividades de trabalho (labor) e obra (work), "a despeito de serem repetidamente usadas como sinônimas". Vejamos como ela trata dessa questão, em relação com a diferença entre objetos de consumo, fruto do trabalho, e de uso: "Parece que a distinção entre trabalho e obra, que os nossos teóricos tão obstinadamente negligenciam e nossas línguas tão aferradamente conservam, torna-se realmente apenas uma diferença de grau quando não se leva em conta o caráter mundano da coisa produzida - sua localização, sua função e a duração de sua permanência no mundo. A distinção entre um pão, cuja 'expectativa de vida' no mundo dificilmente ultrapassa um dia, e uma mesa, que pode facilmente sobreviver a gerações de homens, é sem dúvida muito mais óbvia e decisiva que a diferença entre um padeiro e um carpinteiro" (Arendt, 2010a, p. 115-116). 
inerente um elemento de ação e, portanto, de natalidade. Além disso, como a ação é a atividade política por excelência, a natalidade, e não a mortalidade, pode ser a categoria central do pensamento político, em contraposição ao pensamento metafísico. (Arendt, 2010a, p. 10)

O homem, como animal laborans (animal trabalhador), tende a destruir o mundo, pois tudo que ele procura fazer é satisfazer vorazmente sua necessidade. O homo faber (homem fabricador) produz o mundo durável que empresta permanência à nossa futilidade. $\mathrm{O}$ homem, pela ação, inicia algo novo, funda corpos políticos, e nunca age apenas sozinho, mas em concerto, pois a ação depende dos outros. A liberdade humana baseia-se natalidade. Vale notar que a crise do mundo moderno passa pela inversão da hierarquia das atividades de trabalho, obra e ação, em favor do trabalho, proclamando a vitória do animal laborans que se nega a qualquer produtividade que não se vincule ao trabalho e ao consumo. "[...] no trabalho e no consumo, o homem é totalmente lançado de volta para si mesmo" (Arendt, 2008b, p. 50). Arendt considera que o século XX foi eminentemente de uma sociedade de trabalhadores, em que os "ideais do homo faber, fabricante do mundo, que são a permanência, a estabilidade e a durabilidade, foram sacrificados à abundância, o ideal do animal laborans" (Arendt, 2010a, p. 156).

Vejamos como Arendt enlaça natalidade e liberdade com a vita activa.

O conceito de liberdade ocupa lugar central na obra de Hannah Arendt, não por sua fecundidade teórica, mas por sua condição propriamente fenomênica. Em um mundo em crise, que segue o curso da ruína que lhe é inerente, a liberdade passa a ser a faculdade humana que nas poucas vezes em que se evidencia é capaz de salvar o mundo, pois somente "a salvação, não a ruína, vem do inesperado, pois é a salvação, e não a ruína, que depende da liberdade e da vontade dos homens" (Arendt, 2008b, p. 101). Para tratar o tema da liberdade, Arendt usa de elementos da linguagem religiosa, embora o teor não o seja. Essa linguagem política revestida de elementos religiosos é marcante no sentido de indicar, não as influências religiosas, mas o ponto no qual foi necessário transcender inevitavelmente os sentidos impostos pelas teorias políticas de cunho filosófico e científico. Também é indicativo do exato ponto em que se deve manter o otimismo em relação às atividades humanas. Ao lado da salvação, Arendt utiliza a ideia de "milagre" para compor sua compreensão sobre o fato da liberdade.

Para a autora, o termo "milagre" não deve ser entendido como de uso exclusivamente religioso. Para desmistificá-lo, ela lança mão da ideia de "infinita improbabilidade" (Arendt, 2004, p. $42 ; 2009$, p. 218-220) no campo físico e biológico. No campo do desenvolvimento natural, ela 
lembra que haver um planeta Terra no universo era uma infinita improbabilidade, tal como disso surgir a vida orgânica e, desta, o ser humano. Nesse sentido, é sim próprio falar de milagres da natureza, isto é, quando acontece algo novo "de maneira inesperada, incalculável e por fim inexplicável em sua causa, [...] justamente como um milagre dentro do contexto de cursos calculáveis" (Arendt, 2004, p. 42). Ou seja, o milagre ocorre na interrupção inesperada de uma sequência de acontecimentos. No caso do "milagre da liberdade" (Arendt, 2004, p. 43), ocorre nos eventos históricos. "Eventos, por definição, são ocorrências que interrompem processos e procedimentos de rotina" (Arendt, 2010c, p. 22). Mas a história é tão contingente quanto a capacidade humana de produzir eventos, isto é, de promover milagres políticos. Os homens realizam o milagre da liberdade na ação, e "por terem recebido o dúplice dom da liberdade e da ação" (Arendt, 2009, p. 220), podem estabelecer a sua própria realidade.

Portanto, a liberdade, enquanto milagre, tem a ver com a capacidade sempre presente de o homem iniciar algo novo. Nesse ponto, Hannah Arendt recorre à concepção de criação de Santo Agostinho, em $A$ Cidade de Deus, naquela que é a citação mais aludida de toda a obra dela: "[Initium] ergo ut esset, creatus est homo, ante quem nullus fuit ("para que houvesse um início, o homem foi criado, sem que antes dele ninguém o fosse')" (Arendt, 2010a, p. 222). Aqui, a leitura arendtiana vai à liberdade como "caráter de existência humana no mundo" (A Arendt, 2009, p. 216), em vez de considerá-la uma disposição íntima. Essa existência consiste em ser "um início e um iniciador" (Arendt, 2009, p. 220). A liberdade não é pensada em sentido físico ou jurídico, tampouco em liberdade para se fazer apenas o que se quiser. Trata-se de uma noção de liberdade ontologicamente fundada e fundamentada na natalidade. Cada homem é ele próprio um começo, por isso pode começar, e a cada nascimento ratifica-se a liberdade no mundo. Nesse sentido, "ser humano e ser livre são uma única e mesma coisa" (Arendt, 2009, p. 216). A concepção de liberdade aceita por Arendt é, por assim dizer, a derivação mais imediata da natalidade, sendo esta tanto fundamento ontológico quanto factual.

\section{O sentido da política}

Para Arendt, a crise do mundo moderno situa-se, dentre outras coisas, no caráter difuso da linha que divide o público e o privado nas condições da vida moderna, o que nos venda sua compreensão adequada. Tal como conhecemos, a polis grega se distingue da esfera privada, constituída pelo lar, da família, e na qual se cuida das questões de ordem econômica, das 
necessidades vitais, detendo o chefe da família um poder despótico sobre ela. A própria palavra “economia" deriva da esfera privada, pois vem de oikos, casa, sendo as normas ou leis que regem a casa, segundo a vontade do chefe. Na concepção grega, não existe nenhum tipo de liberdade na esfera privada. No lar, seus habitantes são cativos da necessidade e submetidos ao poder do chefe. Para alcançar a liberdade, o chefe da família tem de sair de casa e estar liberado das necessidades. Essa liberação é, por sua vez, a primeira condição da liberdade mais ampla, na polis. A esfera privada é aquela na qual os indivíduos não aparecem à luz do público, ficando imersos na privatividade, sendo as atividades desenvolvidas, não para o mundo, mas para a manutenção da vida. É, por excelência, a esfera do trabalho. Em princípio, os assuntos privados não tinham importância pública e os assuntos públicos não intervinham na privatividade. Eram esferas independentes entre si, sendo que os direitos dos pais sobre os filhos e o poder do chefe sobre a família e os escravos não eram questionados na esfera pública.

Arendt explica a base grega de sua oposição entre público e privado:

Segundo o pensamento grego, a capacidade humana de organização política não apenas é diferente dessa associação natural cujo centro é o lar (oikia) e a família, mas encontra-se em oposição direta a ela. O surgimento da cidade-Estado significou que o homem recebera, "além de sua vida privada, uma espécie de segunda vida, o seu bios politikos. Agora cada cidadão pertence a duas ordens de existência; e há uma nítida diferença em sua vida entre aquilo que lhe é próprio (idion) e o que é comum (koinon)" [Werner Jaeger]. Não se tratava de mera opinião ou teoria de Aristóteles, mas de simples fato histórico que a fundação da pólis foi precedida pela destruição de todas as unidades organizadas à base do parentesco, tais como a phratria e a phyle. De todas as atividades necessárias e presentes nas comunidades humanas, somente duas eram consideradas políticas e constituíam o que Aristóteles chamava de bios politikos: a ação (praxis) e o discurso (lexis), das quais surge o domínio dos assuntos humanos (ta ton anthropon pragmata, como chamava Platão), de onde está estritamente excluído tudo o que é apenas necessário ou útil. (Arendt, 2010a, p. 28-29)

A esfera pública, na forma grega, era a polis, isto é, o espaço para a política, para assuntos públicos. Mas nem todos os homens eram cidadãos. Só podiam participar das assembleias aqueles que já se vissem liberados das necessidades vitais. Comerciantes, por exemplo, por se ocuparem de coisas de ordem econômica, não eram considerados livres para a polis. Aquele que se decidisse pela vida na polis deveria dedicar-se aos assuntos da cidade, e os assuntos privados não poderiam, em princípio, intervir em suas opiniões. A forma de governo era a democracia, cuja máxima expressão foi Atenas, e sua forma de participação era direta. Livres da força coercitiva da necessidade e postos entre outros que são igualmente livres, os cidadãos iam às assembleias e cada qual discursava sobre sua opinião (doxa), que uma vez postas em votação, aquela que obtivesse 
maioria se impunha com força de consenso. Na polis não se admitia violência nem coação, mas a vitória dever-se-ia à persuasão, exclusivamente pelo discurso. A esse respeito, diz Arendt:

[...] os gregos, convivendo em uma polis, conduziam seus negócios por intermédio do discurso, através da persuasão (peithein), e não por meio de violência e através da coerção muda. Consequentemente, quando homens livres obedeciam a seu governo, ou às leis da polis, sua obediência era chamada peitharkhía, uma palavra que indica claramente que a obediência era obtida por persuasão e não pela força. Os bárbaros eram governados pela violência, e os escravos eram forçados ao trabalho, e desde que ação violenta e labuta assemelham-se no fato de não exigirem o discurso para serem eficientes, bárbaros e escravos eram áneu lógou, isto é, não viviam uns com os outros fundamentalmente através da fala. (Arendt, 2009, p. 50)

É nessa diferenciação básica que Arendt se movimenta em sua teoria política. Não que ela proponha, em pleno século XX, que haja uma nova polis. O que ela percebe é que essa diferenciação das esferas da vida entrou em colapso na modernidade, e junto com ela, declinaram as experiências do homem público e o sentido de liberdade política.

Arendt encara a esfera pública basicamente de três formas: como espaço para a aparência, como mundo comum e como esfera política. Portanto, o termo "público" não é restritivo quanto ao trabalho e à obra. Mas há, em Arendt, um sentido político por excelência, pois aparência (ver e ser visto, falar e ser ouvido) e o mundo comum (no qual se pode sentir-se em casa) são imprescindíveis à ação, visto que ambos guardam íntima relação com a pluralidade.

Não apenas o homem, mas qualquer ser vivo, “depende de um mundo que solidamente aparece como a locação de sua própria aparição, da aparição de outras criaturas com as quais contracena e de espectadores que reconhecem e certificam sua existência" (Arendt, 2010b, p. 38). Isso é o que caracteriza o "público" como aparência. Assim, a aparência no domínio público é constitutiva de nossa realidade. Aquilo de nós que não aparece, tais como sentimentos, paixões, deleites e pensamentos, "levam uma espécie de existência incerta e obscura" (Arendt, 2010a, p. 61), a menos que venham a emergir, voluntariamente ou não, como elemento de aparição pública. Ao se falar em público de experiências provenientes da privatividade ou da intimidade, por mais que se perca em intensidade, assumem uma realidade no domínio público enquanto aparência, isto é, passam a existir para os outros. O público como fenômeno da aparência nos põe na "presença de outros que veem o que vemos e ouvem o que ouvimos" (Arendt, 2010a, p. 61), garantindo-nos a realidade do mundo e a nossa. 
O termo "público", com significado de mundo comum, "tem a ver com o artefato humano, com o que é fabricado pelas mãos humanas, assim como com os negócios realizados entre os que habitam o mundo feito pelo homem" (Arendt, 2010a, p. 64). O mundo comum, ao mesmo tempo em que reúne os homens em companhia dos outros, é também comum enquanto espaço de distinção, o que impede que os indivíduos percam a sua individualidade ou singularidade. O mundo comum indica que a esfera pública não é de indivíduos idênticos, mas iguais em sua singularidade, que constroem e possuem interesse no mesmo objeto, mesmo visto por perspectivas diversas. A autora utiliza o exemplo da mesa: uma obra do homo faber que cumpre o papel de espaço-entre, isto é, ao mesmo tempo em que separa aqueles que estão ao seu redor, como objeto do interesse comum, parte do mundo comum, relaciona-os entre si.

Ainda mais importante que os artefatos comuns do mundo, são os assuntos comuns, ou melhor, as significações compartilhadas. Para Arendt, é impossível se conhecer o mundo como é realmente se não se entendê-lo como comum a muitos. $\mathrm{O}$ mundo está entre eles e se mostra diferentemente a cada um, sendo compreensível apenas "na medida em que muitos falarem sobre ele e trocarem suas opiniões [...] uns com os outros e uns contra os outros" (Arendt, 2004, p. 60), o que possibilita o surgimento de um mundo objetivo na medida em que comumente é visto de vários ângulos. Daí resulta a identificação entre "viver-num-mundo-real e o falar-sobre-ele-comos-outros" (Arendt, 2004, p. 60). Isso significa que a realidade do mundo comum depende inexoravelmente do senso comum.

Arendt não atrela a ideia de senso comum à de conhecimento vulgar, em nível mais baixo que os conhecimentos elaborados, tais como filosóficos ou científicos. Ao contrário, em termos políticos o senso comum é de maior valor que qualquer orientação epistemológica. Ela elabora o conceito de senso comum basicamente a partir de duas fontes: sua análise sobre a situação do senso comum entre os romanos e seu significado na filosofia política de Kant. Acerca desse último, ao responder à questão do julgamento, ou mais especificamente, à pergunta de como escolher aprovar ou desaprovar, Arendt afirma ser o critério a comunicabilidade, ou seja, o julgamento é realizado com base no mundo comum, e "a regra de sua decisão é o senso comum" (Arendt, 1993, p. 89). Portanto, para se exercer a faculdade do juízo, "julgamos como membros de uma comunidade" (Arendt, 1993, p. 93), sendo o senso comum, por consequência, um senso comunitário. O senso comum (sensus comunis) e cada sentido individual (sensus privatus) são complementares, e embora o sensus privatus pareça totalmente incomunicável, ele está "enraizado 
nesse senso comunitário e, portanto, aberto à comunicação uma vez que tenha sido transformado pela reflexão" (Arendt, 1993, p. 93). A própria terminologia kantiana, que usa as expressões em latim, é especialmente notada por Arendt. O termo latino sensus é vinculado aos sentidos, na expressão sensus privatus. Nesse âmbito, enquanto os sentidos são próprios de todos os seres que estão aparelhados pelos respectivos órgãos, o sensus comunis é especificamente humano: é "um sentido extra - como uma capacidade extra do espírito [...] - que nos ajusta a uma comunidade", sendo que nele se manifesta a "própria humanidade do homem" (Arendt, 1993, p. 90). Arendt carrega esse significado kantiano de senso comum por toda sua obra, como um sexto sentido que ajusta os demais sentidos ao mundo comum.

Politicamente falando, o senso comum é a base da troca de opiniões e da ação pelo discurso. O discurso depende do senso comum, pois não é meramente expressão, mas comunicação das opiniões, pois para exprimir dor ou fome não é necessário o discurso, o que, entretanto, é indispensável a qualquer perspectiva de mundo. A realidade, como visto, não pode ser compreendida sem o senso comum, pois as propriedades sensoriais não são suficientes para apreendê-la. O senso comum é o sexto sentido que nos certifica da realidade e se impõe ao sensorialmente percebido.

Acerca do significado de senso comum entre os romanos, Arendt atribui a eles o seu desenvolvimento no nível de "parâmetro mais elevado na administração dos assuntos públicopolíticos" (Arendt, 2008a, p. 87). Isso porque para os romanos o corpo político é estabelecido pela fundação, e, por isso, o senso comum é alimentado pela tradição. Há, então, íntima ligação entre senso comum e rememoração. "Os juízos do senso comum impostos pela tradição extraíram e preservaram do passado tudo que foi conceptualizado pela tradição $e$ era ainda aplicável às presentes questões" (Arendt, 2008a, p. 87-88). Ou seja, a rememoração se realiza sobre o legado do mundo comum.

A esfera pública, seja enquanto espaço para a aparência seja como mundo comum, tem sua plena realização na política, mais uma vez referenciada na antiguidade grega e romana, pois considera momentos exemplares em que a atividade política teve atribuídas maiores consideração e dignidade. Arendt explica que a organização política não se distingue do lar e da família apenas em nível, mas também em sentido, pois está em oposição direta à esfera privada. A bios politikos não é mero desdobramento da vida. Aquilo que é próprio (idion) e aquilo que é comum (koinon) pertencem a duas ordens opostas de existência. O cidadão, com o surgimento da cidade-Estado, 
não é constituído de duas dimensões da mesma vida, mas passa a ter duas vidas: uma natural, outra política. Somente duas atividades, dentre todas as que podem ser consideradas comunitárias, merecem a dignidade da bios politikos: a ação (práxis) e o discurso (lexis). Assim, o domínio público só é propriamente político quando em atividades que excluem a necessidade, portanto o trabalho, e a utilidade, isto é, a obra. Ação e discurso constituem, então, o "domínio dos assuntos humanos" (Arendt, 2010a, p. 29), à medida que a ação é a única atividade que se dá entre homens e sem mediação de artefatos.

Mas qual é o sentido da política? Qual sua razão de ser? O sentido ou a raison d'être da política é a liberdade (cf. Arendt, 2009, p. 192; 2004, p. 38), e "seu domínio de experiência é a ação" (Arendt, 2009, p. 192). Até agora, abordou-se a liberdade vinculada à possível novidade presente em cada nascimento. Essa primeira aproximação era preliminar. Deter-se-á um pouco nas noções de liberdade e da ação sob o aspecto da experiência política.

Para Arendt, como vimos, a ação é a mais elevada das atividades da vita activa. Ao contrário do trabalho e da obra, ela "jamais é possível no isolamento" (Arendt, 2010a, p. 235), precisando da presença dos outros. Isso porque, do ponto de vista político, possuir o dom da liberdade pelo nascimento não torna o indivíduo livre, e essa liberdade precisa se manifestar em um espaço politicamente organizado, "no qual cada homem livre poderia inserir-se por palavras e feitos” (Arendt, 2009, p. 194). Essa inserção é a ação. A liberdade surge simultaneamente à ação que a realiza. "Os homens são livres [...] enquanto agem, nem antes, nem depois; pois ser livre e agir são uma mesma coisa" (Arendt, 2009, p. 199), residindo nisso a identificação entre liberdade política e ação. A polis é loquaz nesse sentido, pois configura uma comunidade política cujo objetivo é "servir aos livres" (Arendt, 2009, p. 201) e cujo sentido é o estabelecimento e a manutenção de um espaço adequado ao aparecimento da liberdade, entendida como virtuosismo.

Há, ao menos, três entendimentos de liberdade que a autora confronta para insistir na necessidade de um espaço para a política no qual se possa agir e ser efetivamente livre: a concepção de liberdade interior, a liberdade como sujeição aos outros, e a ideia de liberdade como liberdade da política. Após o declínio da polis, na Antiguidade tardia, a interioridade surge como região do eu em que aqueles que não podem mais experimentar a liberdade na esfera política se refugiam da coerção externa. "[...] o homem nada saberia da liberdade interior se não tivesse antes experimentado a condição de estar livre como uma realidade mundanamente tangível" (Arendt, 2009, p. 194). Contra o argumento da liberdade interior, há o fato de ter sido a liberdade um 
atributo do homem livre: primeiramente respondendo à condição de liberação do jugo da necessidade e, em segundo lugar, condicionado à companhia dos outros que estivessem no mesmo estado. A liberação da necessidade capacitava o indivíduo "a se mover, a se afastar de casa, a sair para o mundo e a se encontrar com outras pessoas em palavras e ações” (Arendt, 2009, p. 194), no espaço público comum. Daí, para Arendt, a liberdade não pode ser atributo daqueles que dominam os outros, pois estes não estão postos diante dos outros como iguais, e, nesse sentido, a relação de domínio e obediência, mesmo em público, não é política nem é ação. A coisa política está centrada na liberdade, sendo esta entendida tanto em sentido negativo quanto positivo: "negativamente como o não-ser-dominado e não-dominar, e positivamente como um espaço que só pode ser produzido por muitos, onde cada qual se move entre iguais" (Arendt, 2004, p. 48). Ação e liberdade dependem da presença dos outros enquanto pares, não sendo a liberdade imediata à liberação. Em sentido grego, "o tirano, o déspota e o chefe de família - mesmo que fossem totalmente libertos e não se sujeitassem a ninguém - não eram livres" ${ }^{4}$ (Arendt, 2011, P. 59, grifo meu; cf. 2009, p. 144). No tocante à liberdade como liberdade da política, Arendt situa correntes do século XVII e XVIII, em especial a vertente contratualista de Hobbes, que equacionava o conceito de liberdade com segurança, em vez de ação, defendendo o abrir-se mão da liberdade pela segurança da vida contra a morte violenta, portanto, abdicando da ação em nome do processo vital subjugada à lógica da necessidade, sendo essa fenda entre liberdade e política ampliada pelas ciências sociais e políticas surgidas nos séculos XIX e XX, na medida em que tornam o governo, visto na fase inicial da Era Moderna como detentor do monopólio do político, em protetor dos interesses sociais e individuais (cf. Arendt, 2009, p. 196).

\section{A esfera social e a perda do mundo e do senso comuns}

\footnotetext{
${ }^{4}$ Arendt continua esse argumento explicando que tanto o tirano quanto o déspota e o chefe de família destroem o espaço no qual poderiam ser livres para agir: "O ponto central da equivalência que Heródoto estabelecia entre liberdade e não domínio era que o próprio dominante em si não era livre; ao assumir o domínio sobre outros, ele se privava daqueles pares em cuja companhia seria livre. Em outras palavras, ele havia destruído o próprio espaço político, daí resultando que não restara liberdade, nem para si, nem para os submetidos a seu domínio. A razão dessa insistência sobre o vínculo entre liberdade e igualdade no pensamento político grego repousava no fato de que a liberdade era entendida como um traço que se manifestava apenas em algumas atividades humanas, e não, de maneira alguma, em todas elas, e que essas atividades apareceriam e seriam reais somente quando fossem vistas, julgadas e lembradas por outros. A vida de um homem livre exigia a presença de outros. A própria liberdade, portanto, exigia um lugar onde as pessoas pudessem se reunir — a ágora, a praça ou a pólis, o espaço político propriamente dito" (Arendt, 2011, p. 59).
} 
Para se compreender a perda do senso comum em Hannah Arendt, é preciso percorrer mais um pouco sua obra, pois, para ela, a falência desse senso alcança o ápice na sociedade de massas. Para tanto, deve se entender como a autora vê a ascensão da esfera social e sua sobreposição às esferas pública e privada, até que se atinge o ponto da sociedade de massas. Melhor dizendo, o que Arendt chama de "esfera social" é um misto de sociedade e sociedade de massas, as quais são, grosso modo, etapas historicamente datadas e sucessivas de uma única esfera de atividades humanas de características pseudopúblicas, no sentido de que, embora coletiva e em circunstância de aparência, limita as possibilidades da ação política.

Arendt vê a necessidade de se distinguir a eclosão da esfera social, própria da era moderna, da confusão terminológica entre os termos "político", que dá sentido forte ao termo "público", e o termo "social", pois esta confusão é mais antiga, ocasionada pela tradução do zoon politikon de Aristóteles por animal socialis de Sêneca, e posterior fusão conceitual de Tomás de Aquino: "homo est naturaler politicus, id est, socialis ('o homem é, por natureza, político, isto é, social')" (Arendt, 2010a, p. 27). Ela interpreta que o uso da palavra "social", de origem romana, indica que o sentido original da experiência da polis havia se perdido, pois ao termo "social" não havia equivalente nem na língua nem no universo intelectual grego. Para ela, o significado político de societas era limitado em relação à semântica grega: "indicava uma aliança entre pessoas para um fim específico, como quando os homens se organizavam para dominar outros ou para cometer um crime" (Arendt, 2010a, p. 28). Para o sentido grego, viver entre os outros em comunidades políticas, como zoon politikon, corresponde àquela segunda natureza em que se pode exercer a liberdade; já o animal socialis estaria vinculado à associação no âmbito ainda da primeira natureza, que para o grego se resolvia no lar. Assim, conclui Arendt, a conotação de social aos olhos gregos não é fundamentalmente humana, pois a "companhia natural, meramente social, da espécie humana era vista como uma limitação imposta a nós pelas necessidades da vida biológica" (Arendt, 2010a, p. 28), o que o animal social humano compartilha com demais animais.

Essa confusão terminológica vem da Antiguidade, assim como o equacionamento teórico entre esfera política e social. Mas isso não era tão problemático na Antiguidade e no Medievo, quanto se tornou na Era Moderna, pois nos períodos pré-modernos os domínios da família e da política sempre estiveram factualmente separados. Na Idade Moderna, a esfera social eclode como uma esfera que não é nem privada nem pública, sendo o Estado nacional sua forma política. $\mathrm{O}$ surgimento da esfera social ocorre em termos da sociedade, no sentido de "boa" sociedade. Arendt 
não desenvolve sistematicamente seu surgimento, mas para ela a sociedade surge nos séculos XVIII e XIX “provavelmente das cortes europeias do período absolutista” (Arendt, 2009, p. 251), a exemplo da Corte de Luís XIV, que ao reunir a nobreza francesa no palácio de Versalhes a transformou em cortesã, reduzindo-a a "insignificância política" (Arendt, 2009, p. 251), pelo envolvimento de seus membros em mesquinhas contendas privadas.

Essa caricatura originária, entretanto, embora ilustrativa, não encerra o significado político do que Arendt chama de sociedade. Por trás das linhas caricaturais, ela percebe a emergência de um complexo cruzamento de novos formatos organizacionais e comportamentais, alinhados a um novo fundamento epistemológico. Ela vê que o formato do Estado-nação tornou-se uma protofamília, em que o campo político se desfigurou em administração de problemas que outrora eram exclusivos da esfera privada. Assim, o termo "sociedade" aufere o significado de "conjunto de famílias economicamente organizadas de modo a constituírem o fac-símile de uma única família sobre-humana" (Arendt, 2010a, p. 34) ${ }^{5}$. Sua forma política é a "nação", e seu fundamento epistemológico (ou, nas palavras de Arendt, seu "pensamento científico") é a economia nacional, ou economia política, o que já demonstra o nível de assimilação de esferas antes contraditórias. Isso significa que a sociedade opera uma profunda transformação nas tradicionais esferas privada e pública, de modo a promover o alargamento do privado, o que, em vez de elevar o privado à dignidade do domínio público, retira a dignidade do público, pois este se vê minguado. Com tal alargamento, "a grandeza [da esfera pública] cedeu lugar ao encanto" (Arendt, 2010a, p. 64), uma vez que o domínio público não pode ser encantador, pois em sua vastidão o irrelevante não pode ser abrigado. No plano do governo, este foi substituído pela burocracia, o governo de ninguém, que supostamente (des)encarna a "opinião única da sociedade educada dos salões" (Arendt, 2010a, p. 49). A política tornou-se uma função na sociedade.

Mas o que para Arendt é decisivo para a vitória da sociedade tanto sobre a política quanto sobre o lar, é que ela exclui ação em todos os níveis, substituindo-a pelo comportamento. “A ação espontânea ou a façanha extraordinária” (Arendt, 2010a, p. 49) são substituídas pelo

\footnotetext{
${ }^{5}$ Arendt relaciona a questão do surgimento da sociedade como grande família ao concomitante declínio da família, nos seguintes termos: "Nesse particular, pouco importa se uma nação se compõe de iguais ou desiguais, pois a sociedade exige sempre que os seus membros ajam como se fossem membros de uma enorme família que tem apenas uma opinião e um único interesse. Antes da moderna desintegração da família, esse interesse comum e essa opinião única eram representados pelo chefe do lar, que comandava segundo essa opinião e esse interesse, e evitava uma possível desunião entre os membros da família. A notável coincidência da ascensão da sociedade com o declínio da família indica claramente que o que ocorreu, na verdade, foi a absorção da unidade familiar por grupos sociais correspondentes" (Arendt, 2010a, p. 48).
} 
comportamento padronizado por regras normalizadoras, o que equivale a uma substancial mudança também na concepção de igualdade. Enquanto a igualdade política estava atrelada à possibilidade do empreendimento imprevisível, portanto, na distinção, a igualdade da sociedade transpôs a diferença para o domínio unicamente privado e criou um falso domínio público no qual impera o comportamento segundo a normalidade. "O que importa é esse equacionamento com a posição social, e é irrelevante se se trata da efetiva posição na sociedade semifeudal do século XVIII, do título na sociedade de classes do século XIX, ou da mera função na atual sociedade de massas" (Arendt, 2010a, p. 49). A esse comportamento social que prescinde do senso de ação, Arendt dá o nome de "conformismo". Ele está tanto na base da ideia moderna de igualdade como na base da ciência da economia, que surgiu concomitante à sociedade e se tornou "a ciência social por excelência" (Arendt, 2010a, p. 51) à medida que os homens "tornaram-se seres sociais e passaram a seguir unanimemente certos padrões de comportamento" (Arendt, 2010a, p. 51), ao ponto de serem passíveis de medição pela estatística, maior instrumento técnico da economia. Isto é, somente quando a sociedade fez do homem um ser de comportamento em grande medida previsível ou conformista, o que dá no mesmo, é que a economia como ciência conseguiu se firmar sobre a esfera pública, normatizando-a como uma grande casa.

Como se pode inferir do dito acima, Arendt entende que a sociedade, ou melhor, a esfera social, passa ao menos por três estágios: sociedade semifeudal (século XVIII), sociedade de classes (século XIX) e sociedade de massas (século XX). No último, a ciência da economia é sucedida por outro modelo científico que Arendt chama de "ciências do comportamento". Para a teórica, a economia tem alcance limitado na imposição de padrões de comportamento, tendo tal poder sobretudo frente àqueles estratos mais abastados da população, que formam a boa sociedade (cf. Arendt, 2009, p. 251). Com o surgimento da sociedade de massas, vários grupos sociais são condensados em uma única sociedade; na era de massas, após três séculos de desenvolvimento, a sociedade alcançou "o ponto em que abrange e controla, igualmente e com igual força, todos os membros de uma determinada comunidade" (Arendt, 2010a, p. 50). O surgimento e o estabelecimento das ciências do comportamento, da "pretensão oniabrangente das ciências sociais [...] [de] reduzir o homem como um todo, em todas as suas atividades, ao nível de um animal comportado e condicionado" (Arendt, 2010a, p. 55), demonstram que a fase final dos desdobramentos da sociedade de massas se dá quando ela atinge todas as camadas da nação e o comportamento social atingiu o status de referência a todos os setores da vida, incluindo os 
âmbitos da vita activa. Na passagem da sociedade à sociedade de massas, o comportamento social se impõe com maior força aos indivíduos, pois não há vias de escape para outro estrato da população que não seja massificado, tornando o conformismo um traço característico da psicologia do homem de massa. $\mathrm{O}$ mundo moderno assistiu à inversão da hierarquia no âmbito da vita activa em favor do trabalho, o que fez desse mundo uma sociedade de trabalhadores. O comportamento social generalizado é o trabalho, sendo que o homem de massa aliena-se do mundo. Arendt caracteriza a psicologia do homem de massa da seguinte forma: sua solidão [loneliness], sua estabilidade e falta de padrões (que se resume ao trabalho e ao consumo), sua capacidade de consumo aliada à inabilidade para julgar, seu egocentrismo e alienação do mundo (cf. Arendt, 2009, p. 150-151).

Os traços psicológicos do homem de massa já estavam presentes no homem da sociedade, sendo a diferença entre o comportamento social e o de massa uma questão numérica. Mas Arendt concebe que haja sociedades de massas em países que não passaram pelo estágio inicial da sociedade. O termo massa possui um significado bastante específico, constitutivo propriamente do mundo moderno, pois não está fundamentado apenas no número de indivíduos, distinguindo-se assim das multidões de períodos anteriores (cf. Arendt, 2008b, p. 422). O que diferencia multidão e massa é que na última, além do dado quantitativo, não há interesses comuns a unir os indivíduos. Portanto, "as massas existem em qualquer país e constituem a maioria das pessoas neutras e politicamente indiferentes" (Arendt, 1989, p. 361). Em situação de massa, o mundo comum perde a capacidade tanto de congregar e relacionar pessoas, isto é, deixa de ser um espaço comum, quanto de separá-las, no sentido de distingui-las politicamente com respeito à singularidade. Falando mais precisamente, o mundo comum não mais se sustenta. Sem ele como garantia de distinção, a sociedade de massas faz com que os indivíduos se comportem como se fossem parte de uma única família, "cada um a multiplicar e prolongar a perspectiva do vizinho" (Arendt, 2010a, p. 71). É nesse sentido que se faz mais audível o alargamento do privado, pois "privado" tem originalmente o sentido de "privativo", em oposição ao público: quem vive por completo de forma privada está privado da realidade em que pode ver e ser visto, do mundo comum, de realizações por palavras e feitos, permanecendo numa esfera ínfima, na qual não tem importância para os outros. Ou seja, está "privado de coisas essenciais a uma vida verdadeiramente humana" (Arendt, 2010a, p. 72). Sem um mundo comum, o homem de massa se torna completamente privado, mas o alargamento do privado, além de findar com experiências substancialmente 
públicas, não significa que resguarda o lar privado, apenas que a lógica do lar atinge o estatuto de público. A esfera privada é também destruída, pois seus membros deixam de se comportar conforme a vontade de um chefe, e assumem um comportamento social, sendo bombardeados por conhecimentos peritos que ensinam e cobram de cada qual o comportamento conforme sua função familiar. A esse respeito, Arendt (cf. Arendt, 2010a, p. 48) observa a coincidência entre a ascensão da sociedade e o declínio da família, considerando tal declínio o ponto em que a segunda é absorvida pela primeira, a grande família social. A esfera social, sua ascensão na sociedade e sua consolidação na sociedade de massas, acaba por provocar o desparecimento tanto da esfera pública, por ter se tornado função da esfera privada, quanto da esfera privada, por ter se tornado o único interesse comum. O declínio do mundo comum, por sua vez, mina o senso comum. Uma característica das massas é que, em sua atividade única de comportamento ao ritmo do trabalho e do consumo, é o contínuo trânsito. Não se veem espaços para a troca de ideias e construção de significações compartilhadas. O senso comum é frequentemente substituído pela vaga ideia de opinião pública.

\section{Considerações finais: o que conservar para não sermos conservadores?}

Ao observar a onda conservadora que toma as ruas, quase que imediatamente somos impelidos a tomar posição entre direita e esquerda (como se estes opostos ainda fizessem algum sentido), entre "coxinha" ou "petralha", sem que examinemos o fato de haver problemas de natureza política que antecede a "bateção" de panelas. E o problema central é o "conformismo", o mero comportamento padronizado que prescinde ao senso de ação; traço do homem de massa, para quem a complexidade da vida e dos assuntos humanos consiste em trabalhar e consumir em estado solidão tão organizada que falta mesmo aquela unidade mínima que corriqueiramente chamamos de senso comum, relegando a políticos e economistas profissionais assuntos sobre os quais todos deveriam tomar parte.

Após nos apropriarmos das categorias do pensamento de Hannah Arendt, não é preciso muita astúcia para se concluir que a onda "conservadora" é, na verdade, "conformista". Tão maior é a indignação do povo com um governo (composto por muitos corruptos, assim como todos que o antecederam), quanto mais o consumo é afetado. Esse é o contexto no qual as perigosas opiniões das camadas mais ricas (a dita boa sociedade), sejam travestidas de linguagem técnico-científica, 
sejam escancaradas em toda sorte de preconceitos, passam a fazer sentido às massas e a insuflá-las o ódio.

À luz de Arendt, há coisas que precisam ser conservadas, em respeito às condições humanas, especialmente a natalidade, para que se possa fugir ao conformismo: criar mais espaços públicos de decisão e reforçar a participação popular, a fim de que se exercite continuamente a ação, e que tal senso de ação possa concorrer com o comportamento; reconhecer o valor político do senso comum (ou bom senso), preâmbulo da ação e vacina coletiva contra os juízos ideológicos dos especialistas; afirmação da pluralidade, da distinção, por meio da aparição e da ação na esfera pública; etc.

Se nem mesmo Arendt ousou ser prescritiva (pois a prescrição é, a rigor, uma contra-ação), não será aqui que o faremos. Mas se fossemos arriscar, decerto é a liberdade, a espontaneidade, a capacidade de empreender algo novo e inusitado, o initium presente em cada recém-chegado, aquilo que deve ser preservado e conservado com todas as nossas forças. Pois na solidão, ainda que envoltos em uma massa de pessoas, não somos nem podemos ser livres.

\section{Referências Bibliográficas}

ARENDT, Hannah. Sobre a Revolução. Trad. Denise Bottmann. São Paulo: Cia. das Letras, 2011. . A condição humana. Trad. Roberto Raposo. Revisão técnica: Adriano Correia. 11. ed. Rio de Janeiro: Forense Univesitária, 2010a. . A vida do espírito. Trad. Cesar A. Almeida, Antônio Abranches, Helena Martins. 2. ed. Rio de Janeiro: Civilização Brasileira, 2010b. 2010c. . Sobre a violência. Trad. André Duarte. 2.ed. Rio de Janeiro: Civilização Brasileira, Perspectiva, 2009.

Entre o Passado e o Futuro. Tradução Mauro W. Barbosa. 6. Ed. São Paulo: . A Promessa da Política. Trad. Pedro Jorgensen Jr. Rio de Janeiro: Difel, 2008a.

Compreender: formação, exílio e totalitarismo (ensaios 1930-1954). Trad. Denise Bottman. São Paulo: Companhia das Letras; Belo Horizonte: UFMG, 2008 b.

. "Trabalho, obra, ação". Trad. Adriano Correia. In: Cadernos de Ética e Filosofia Política. $\mathrm{n}^{\circ}$ 7, p. 175-201, 2005.

Janeiro: Bertand Brasil, 2004.

. O que é política. Compilação de Ursula Ludz. Trad. Reinaldo Guarany. 5. Ed. Rio de Dumará, 1993.

Lições sobre a filosofia política de Kant. Trad. André Duarte. Rio de Janeiro: Relume1989.

. Origens do totalitarismo. Trad. Roberto Raposo. São Paulo: Companhia das Letras: 